\title{
news and miscellanea
}

\section{NEWW: New Approaches to European Women's Writing (before 1900)}

\author{
Dr Suzan van Dijk (University of Utrecht, Netherlands), \\ Dr Ursula Stohler (University of Bern, Switzerland)
}

Dr Suzan van Dijk from the University of Utrecht in the Netherlands is currently preparing a large European research project on the writings of European women authors before 1900, and in particular the links and influences between them as they are to be found on a European scale, including those between the Western and the Eastern parts of the continent.

This project, entitled NEWW: New Approaches to European Women's Writing (before 1900), emerged from a series of preliminary projects which have been financed by the NWO (Netherlands Organization for Scientific Research) since 1997. Those earlier projects were smaller in scope and investigated in particular the literary relations between France and the Netherlands, as well as compiling a large-scale inventory of the Dutch reception of European women's writing. It includes an on-line database that documents the reception of these writings and hyperlinks them to primary texts, translations, comments, etc. as far as they exist on the Internet. Otherwise, references are provided to classic paper versions. This NEWW project responds to an increasing interest among feminist scholars in investigating the writings of female authors before 1900 and in situating them within the cultural context of the time of their production.

\section{An Example: Russia}

Taking Russia as a case study, the ensuing explanations exemplify this approach. In the domain of Russian studies, the interest in women's writing manifests itself in a number of publications that have appeared in recent years. They include studies on particular women writers, investigations of the socio-cultural background that affected female authorship, as well as anthologies and dictionaries providing essential information on the lives and works of various of female authors. ${ }^{1}$ 
However, there are still many Russian women authors who have not yet received proper scholarly attention. A look at the Bibliograficheskii slovar' russkikh pisatel'nits (Bibliographical dictionary of Russian women writers) by the nineteenth-century philologist Nikolai Golitsyn (1836-1893), first published in 1889, gives an idea of the number of such writings. ${ }^{2}$ It lists over 1200 entries on writings by Russian women, most of them dating from the eighteenth and the nineteenth centuries. Academic studies about these works, however, have appeared on only a fraction of them. An elementary problem for researchers interested in studying any of these writings is that this bibliographical dictionary is only available in very few university libraries. In addition, even scholars who do have access often face difficulties when they obtain copies of the writings mentioned there. In many Russian libraries it is not permitted to make photocopies of texts that appeared before 1900; texts cannot be ordered via interlibrary loans, nor can they be studied anywhere other than in the respective library.

Some feminist scholars have therefore endeavoured to make such works available to a larger public. An encouraging example is Professor Elisabeth Cheauré from the Department of Slavonic Studies at the University of Freiburg im Breisgau in Germany. In close cooperation with the library of the Moscow State University, she has established an extensive collection that holds photocopies of primary works by Russian women authors, secondary literature, as well as theoretical studies on gender issues in Russia. Interested scholars may order photocopies of these works, which are not usually available via interlibrary loan; an on-line edition of the collection is also in preparation. Other, minor digitalizing projects in recent years have attempted to achieve similar objectives, for instance The Corinna Project by Dr Ursula Stohler hosted at the Department of Russian Studies at the University of Exeter in the United Kingdom.

Once works by Russian women writers have come to the attention of a larger number of scholars, it might be interesting to investigate how these Russian women authors have responded to each other. The following example of two Russian women authors, Anna Volkova (1781-1834) and Alexandra Khvostova (1767-1853), illustrates this problem. ${ }^{3}$ Scholars have only recently begun to pay attention to them; however, the mutual impact of each other's work has not yet been explored. What is indeed of particular interest is the fact that Volkova openly acknowledged the importance of one of Khvostova's works. In 1807 Volkova wrote a poetic version of an essay published by Khvostova several years previously, in 1796. In a footnote Volkova refers to the original text and asks its author for permission to use it as a basis of her own text. ${ }^{4}$ It may well be fruitful to study the extent to which such links existed between works of women authors, in particular lesser known ones, who wrote in the same language.

Furthermore, the influence of texts written by women from different cultures could well prove intriguing. One may assume, for instance, that the meditative idylls by the French seventeenth-century woman poet Antoinette Deshoulières (ca. 1638-1694) had a greater impact on Sentimentalist Russian women's writing at the end of the eighteenth century than has been seen so far. ${ }^{5}$ This type of interrelationships between the writings of women from different countries will have to be investigated in order to build a complete picture of the cultural context in which women's writing took place.

It could be useful to focus on specific cultural themes that predominated during a particular period and to which women writers from different countries seemed to 
respond. Such themes should be situated on a transnational or a European level. An example might be the question of natural rights. This is a subject that women such as the French political activist and writer Olympe de Gouges (1748-1793), as well as the Russian Sentimentalist poet Mariia Bolotnikova (published in 1817, dates of birth and death unknown) addressed in their writings. However, it has never been the topic of an exhaustive, cross-cultural study. ${ }^{6}$

\section{The Near Future}

In order to examine transnational cultural themes that were relevant for women's writing before 1900, scholars from different countries will have to cooperate.

The electronic database created by van Dijk provides an ideal foundation from which further work can develop. Upcoming research activities should indeed have the benefit of all relevant online resources - databases and collections of texts, such as those by Cheauré and Stohler - which can be linked to the WomenWriters database. The whole structure will serve as a 'virtual collaboratory' where researchers of women's literary history can 'meet' and share their materials. This is of course particularly relevant for the comparative study of reception of one and the same writer in different countries, as has been shown for the case of George Sand in nineteenth-century Germany, Russia, the Czech lands and Greece. ${ }^{7}$ In the course of 2008 van Dijk and her team are preparing an international research project involving a number of researchers from various countries, for which European funding will be requested. If you are interested in this project, please do not hesitate to contact us, either via the website www.womenwriters.nl, or by writing to Stohler or van Dijk.

\section{More information}

- Dr Suzan van Dijk (Suzan.vanDijk@let.uu.nl) New Approaches to European Women's Writing (before 1900) http://www.womenwriters.nl

- Prof. Dr Elisabeth Cheauré (elisabeth.cheaure@slavistik.uni-freiburg.de) Literaturwissenschaftliche Spezialsammlung "Frauen und Frauenbild in der russischen Kultur" http://www.slavistik.uni-freiburg.de/inpers/litspez

- Dr Ursula Stohler (ursula.stohler@edu.unibe.ch) The Corinna Project http://www.projects.ex.ac.uk/corinna/

\section{$\diamond$ Notes}

1. Viktoriia Uchenova, ed., Tsaritsy muz: russkie poetessy XIX-nachala XX vv (Queens of the muses: Russian women poets from the nineteenth to the beginning of the twentieth centuries), Moscow: Sovremennik, 1989; Mikhail Fainshtein, Pisatel'nitsy pushkinskoi pory: Istoriko- 
literaturnye ocherki (Women writers of the time of Pushkin: Historico-literary studies), Leningrad: Nauka, 1989; Joe Andrew, 'Radical Sentimentalism or Sentimental Radicalism? A Feminist Approach to Eighteenth-Century Russian Literature', in Discontinuous Discourses in Modern Russian Literature, eds. Catriona Kelly et al., London: Macmillan, 1989, 136-156; Frank Göpfert, ed., Russland aus der Feder seiner Frauen: Zum femininen Diskurs in der russischen Literatur (Russia from its women's quill: On the feminine discourse in Russian literature), Munich: Sagner, 1992; Catriona Kelly, A History of Russian Women's Writing, Oxford: Clarendon Press, 1994; Marina Ledkovsky et al., eds., Dictionary of Russian Women Writers, London: Greenwood Press, 1994; Toby Clyman and Diana Greene, eds., Women Writers in Russian Literature, London: Praeger, 1994; Bayara Aroutunova, Lives in Letters: Princess Zinaida Volkonskaya and her Correspondence, Columbus, OH: Slavica Publishers, 1994; Mikhail Fainshtein, ed., Russkie pisatel'nitsy i literaturnyi protsess $v$ kontse XVIII - pervoi treti XX vv. (Russian women writers and the literary process at the end of the eighteenth to the first third of the twentieth century), Wilhelmshorst: Göpfert, 1995; Helena Goscilo and Beth Holmgren, eds., Russia - Women-Culture, Bloomington, IN: Indiana University Press, 1996; Christina Parnell, ed., Frauenbilder und Weiblichkeitsentwürfe in der russischen Frauenprosa: Materialien des wissenschaftlichen Symposiums in Erfurt 1995 (Images of women and concepts of femininity in Russian women's prose: Materials of the academic symposium in Erfurt, 1995), Frankfurt am Main: Lang, 1996; Wendy Rosslyn, Anna Bunina (17741829) and the Origins of Women's Poetry in Russia, Lewiston: Mellen, 1997; Rafail Ganelin, ed., O blagorodstve i preimushchestve zhenskogo pola: Iz istorii zhenskogo voprosa $v$ Rossii (On the nobleness and the advantage of the female sex: The history of the woman question in Russia), St Petersburg: Sankt-Peterburgskaia Gosudarstvennaia Akademiia Kul'tury, 1997; Frank Göpfert and Mikhail Fainshtein, eds., Predstatel'nitsy muz: Russkie poetessy XVIII veka (Women representatives of the muses: Russian women poets of the eighteenth century), Wilhelmshorst: Göpfert, 1998; Elisabeth Cheauré, ed., Pol-Gender-Kul'tura: Nemetskie i russkie issledovaniia (Sex-gender-culture: German and Russian studies), Moscow: Rossiiskii gosudarstvennyi gumanitarnyi universitet, 2000; Catriona Kelly, Refining Russia: Advice Literature, Polite Culture, and Gender from Catherine to Yeltsin, Oxford: Oxford University Press, 2001; Adele Barker and Jehanne Gheith, eds., A History of Women's Writing in Russia, Cambridge, UK: Cambridge University Press, 2002; Robin Bisha, Russian Women, 1698-1917: Experience and Expression, Bloomington, IN: Indiana University Press, 2002; Wendy Rosslyn, ed., Women and Gender in Eighteenth-Century Russia, Aldershot, UK: Ashgate, 2003.

2. Nikolai Golitsyn, Bibliograficheskii slovar' russkikh pistatel'nits (Bibliographical dictionary of Russian women writers), St Petersburg, 1889; repr. St Petersburg: Otdeleniia russkago iazyka i slovesnosti imperatorskoi akademii nauk, 1891; repr. Leipzig: Zentralantiquariat der Deutschen Demokratischen Republik, 1974.

3. Anna Volkova, Stikhotvoreniia (Poems), St Petersburg: Morskaia Tipografiia, 1807; Aleksandra Khvostova, Otryvki (Fragments), St Petersburg: Tipografiia gosudarstvennoi meditsinskoi kollegii, 1797.

4. Khvostova, 'Rucheek', in Otryvki, 31-48; Volkova, 'Rucheek', 74-87.

5. Antoinette du Ligier de La Garde Deshoulières, Poésies de Mme Deshoulières: Nouvelle édition (Poems by Mme Deshoulières: New edition), Bruxelles, 1740.

6. Olympe de Gouges, Écrits politiques (Political writings), ed. Olivier Blanc, Paris: côtéfemmes editions, 1993; Mariia Bolotnikova, Derevenskaia lira, ili chasy uedineniia (The country lyre, or hours of solitude), Moscow: Tipografiia Reshetnikova, 1817.

7. Françoise Genevray, 'Vassili Botkine, George Sand et l'alliance intellectuelle francoallemande' (Vassili Botkine, George Sand and the Franco-German intellectual alliance), in George Sand: La réception hors de France au XIXe siècle (George Sand: Her reception outside France in the nineteenth century), eds. Suzan van Dijk and Kerstin Wiedemann, Numéro spécial de la revue 
Oeuvres E Critiques (Special issue of the journal Works and Reviews) vol. 28, no. 1 (2003): 49-75; Suzan van Dijk and Marianne Walle, 'Les "George Sand" étrangères: Auto-appellation et possibilité de s'identifier: À partir du cas de Bozena Nemcova' (The 'George Sands' abroad: Selfimage and potential self-identification: Based on the case of Bozena Nemcova), in George Sand, eds. van Dijk and Wiedemann, 76-101; Gabrielle Martel Cothereau, Irini Rizaki, and Suzan van Dijk, 'George Sand et les presses féministes étrangères à la fin du XIXe siècle: Les cas de la Grèce et des Pays-Bas' (George Sand and the feminist press abroad at the end of the nineteenth century: The cases of Greece and the Netherlands), in George Sand, eds. van Dijk and Wiedemann, 132-156. 